\title{
KAJIAN TEKSTUR DRAMATIK LAKON MINTARAGA SAJIAN WAYANG WONG SRIWEDARI
}

\author{
Wisnu Samodro \\ Program Pascasarjana \\ Institut Seni Indonesia Surakarta \\ JI. Ki Hadjar Dewantara No. 19 Kentingan, Jebres, Surakarta, 57126 \\ Email : wisnu.samodro@yahoo.co.id
}

\begin{abstract}
ABSTRAK
Penelitian berjudul " Kajian Tekstur Dramatik Lakon Mintaraga Sajian Wayang Wong Sriwedari” merupakan penelitian kualitatif dengan cara melihat pertunjukan dan menganalisis menggunakan teori Tekstual. Teori ini dikemukakan oleh Satoto yang mengungkapkan bahwa tekstur dramatik adalah sesuatu yang terindera. Hasil penelitan ini mengungkap berbagai elemen pertunjukan meliputi dialog, iringan musik dan spektakel. Dialog dapat didengar pilah atau tidaknya yang disesuaikan dengan karakter tokoh yang dimainkan, iringan musik dapat didengar dan dikaji mengenai keselarasan dengan adegan yang dimainkan sedangkan spektakel dapat dilihat dengan indera penglihatan mengenai bentuk setting, properti dan tata cahaya yang digunakan dalam pertunjukan Wayang Wong Sriwedari Lakon Mintaraga.
\end{abstract}

Kata kunci: Tekstur dramatik, Dialog, Spektakel.

\begin{abstract}
ABSTRAK
The research entitled "Kajian Tekstur Dramatik Lakon Mintaraga Sajian Wayang Wong Sriwedari" is a qualitative research by looking at performances and analyzing using Textual theory. This theory was put forward by Satoto. It says that dramatic texture is something that is sensed. The results of this research reveal the various elements of the show including dialogue, musical accompaniment and spectacles. Dialogue can be heard according to the characters being played, musical accompaniment can be heard and studied in harmony with the scene played, while the spectacle can be seen regarding to the form of setting, properties and lighting used in the Wayong Wong Sriwedari performance lakon Mintaraga .
\end{abstract}

Keywords: Dramatic Texture, Dialogue, Spectacles.

\section{A. Pengantar}

Wayang wong merupakan salah satu bentuk kesenian yang telah mengalami puncak keemasan dan dianggap sebagai kesenian yang adi luhung. $\mathrm{Di}$ dalam pertunjukan wayang wong terdapat berbagai ajaran kehidupan meliputi nilai-nilai Ketuhanan, kepahlawanan, rohaniah, pengorbanan serta nilai-nilai luhur yang mengedepankan ajaran hidup manusia. Pertunjukan wayang wong sebagai salah satu bentuk teater tradisi mempunyai media ungkap yang paling lengkap, sebab mempunyai penyajian cerita melalui serentetan adegan-adegan, dengan pemeran-pemeran yang melakukan dialog, menari serta iringan musik (Hersapandi 1998:4). Menurut Hersapandi, sebuah pertunjukan wayang wong memiliki beberapa unsur. Unsur tersebut dibagi menjadi dua yakni unsur pokok dan unsur pendukung. Unsur pokok dalam wayang wong meliputi lakon, catur, tari, dan karawitan iringan, sedangkan unsur pendukung meliputi tata cahaya, busana, dan properti. Unsur pokok dan unsur pendukung dalam wayang wong tidak bisa berdiri sendiri karena harus saling terkait ( 1998: 67-680). Wayang kulit dan wayang wong di Jawa hidup dan berkembang secara berdampingan, keduanya saling mempengaruhi. Wayang wong dapat dikatakan sebagai drama tari berdialog yang menggunakan tari, tembang, dan aktor-aktornya dilakukan oleh manusia, sedangkan wayang kulit (purwa) diperankan oleh boneka kulit yang dimainkan oleh dalang. Cerita wayang kulit dan wayang wong ialah epos Mahabarata dan Ramayana. Wayang wong merupakan sebuah genre tari yang bisa dikatakan sebagai pertunjukan total (total theatre) yang di dalamnya tercakup seni tari, sastra, drama, musik, dan seni rupa. Konsepsi dasar wayang wong mengacu pada wayang kulit purwa, maka personifikasi wayang kulit purwa dan transformasi wayang kulit ke dalam wayang wong 


\section{GEEAR Jumal sai isubya}

sebagai ekspresi arstistik serta langkah kreatif dan inovatif dalam kesenian tentu melahirkan tata nilai baru perkembangan seni wayang. Seni tradisional wayang wong tumbuh dan berkembang pesat di daerah Yogyakarta dan Surakarta. Namun demikian, menurut Winoto (2006), seni pertunjukkan wayang wong pada masing-masing daerah memiliki gaya tersendiri. Salah satu kelompok pertunjukkan wayang wong yang terkenal di daerah Surakarta adalah kelompok Wayang Wong Sriwedari. Kelompok ini merupakan sebuah organisasi sosial yang terdiri dari beberapa pekerja seni yang mempuyai bekal dan keahlian yang berbedabeda, antara lain; sutradara, penari, pengrawit, dalang, pinata cahaya, dan kru pertunjukkan. Wayang Wong Sriwedari, yang berfungsi sebagai presentasi estetis, memiliki sejarah dan perkembangan yang begitu panjang yang dimulai dari seni istana menjadi seni komersial (Azhari, 2015).

Menurut Pigeud (dalam Hersapandi, 1999), perkembangan wayang wong sampai pada tahun 1895 tidak pernah sekalipun ditampilkan di luar istana dikarenakan wayang wong adalah hiburan yang hanya diperuntukkan untuk Raja dan keluarga keraton, namun pada perkembanganya pada tahun 1911 untuk pertama kalinya oleh Gan Kam didirikan rombongan wayang komersial yang bertujuan untuk dipertunjukan kepada masyarakat dan bukan lagi untuk kalangan istana. Penonton diwajibkan membayar tiket untuk dapat melihat pertunjukan. Dari situlah, kelompok Wayang Wong Sriwedari terbentuk dengan adanya dukungan beberapa anggota wayang wong panggung yang telah memiliki pengalaman cukup tinggi dalam pementasan keliling kota-kota besar di Indonesia. Selain difungsikan sebagai media komersialisasi, kelompok ini juga didirikan guna melengkapi fasilitas hiburan yang ada di Taman Sriwedari atau dikenal sebagai Kebon Raja.

Pada masa-masa kejayaannya sekitar tahun 1970 hingga 1990 an, pertunjukkan yang digelar oleh Wayang Wong Sriwedari merupakan sebuah pertunjukkan yang dinanti-nanti, tidak hanya oleh warga pribumi namun juga oleh masyarakat Cina (Hersapandi, 1999). Namun seiring dengan semakin maju dan pesatnya pembangunan, Wayang Wong Sriwedari mengalami kemunduran yang signifikan. Pembangunan di sini berkonotasi sebagai upaya perbaikan akses dan standar kehidupan manusia sehingga membawa dampak terhadap pandangan orang berkenaan dengan seni pertunjukkan wayang wong (Azhari, 2015). Nampaknya kemunduran dari Wayang Wong Sriwedari menjadi sorotan dari pemerintah Surakarta saat itu. Pemerintah Surakarta mempunyai niat untuk mengembangkan kesenian yang hampir mati itu karena merupakan produk budaya yang harus dilestarikan.

Sejak tahun 2001, Dinas Pariwisata Seni dan Budaya melalui surat keputusan Wali Kota Surakarta Nomor 25 tahun 2001, Wayang Wong Sriwedari dalam struktur organisasinya dikelola oleh Seksi Pengendalian dan Pelestarian Aset Seni dan Budaya. Sebagai bagian dari institusi pemerintah, maka dukungan dana pembiayaan produksi serta gaji seluruh anak wayang dan staf, pembiayaan gedung beserta fasilitasnya menjadi tanggung jawab Dinas yang membawahinya tersebut. Hal tersebut merupakan bukti dari pemerintah yang peduli terhadap kesenian dan akhirnya Wayang Wong Sriwedari menjadi semakin eksis. Sejumlah prestasi pun pernah diraih oleh kelompok wayang ini, salah satunya tercatat di Museum Rekor Muri sebagai organisasi Wayang Wong tertua di Jawa Tengah yang masih aktif. Selain itu, Wayang Wong Sriwedari juga sering menggelar pertunjukkan di berbagi kota besar seperti Denpasar dan Jakarta serta di negara Eropa Barat seperti Jerman.

Pertunjukkan Wayang Wong Sriwedari biasanya digelar di Gedung Wayang Wong Sriwedari, sebelah Barat Museum Radya Pustaka. Pertunjukkan wayang wong oleh kelompok ini dilakukan setiap hari Senin sampai Sabtu, mulai pukul 20.00-23.00 WIB. Tiket masuk untuk pertunjukkan pun relatif sangat murah dan dapat dijangkau oleh hampir semua kalangan. Hanya dengan membayar uang tiket sebesar tujuh ribu rupiah, pengunjung sudah dapat menikmati sajian wayang orang yang dilaksanakan oleh kelompok ini.

Salah satu pertunjukkan yang dilakukan oleh kelompok Wayang Wong Sriwedari adalah sebuah lakon yang berjudul Mintaraga. Cerita Mintaraga sendiri merupakan gubahan dari Serat Arjuna Wiwaha karya Empu Kanwa yang sekarang lebih dikenal sebagai Begawan Ciptaning yang dibangun pada jaman Surakarta awal yang merupakan jarwan 'terjemahan' dari epos Kakawin Arjuna Wiwaha (Sulaksono, 2011. Tesis). Sementara itu, cerita Arjuna Wiwaha merupakan bagian ketiga kitab Mahabrata, yaitu bagian Wanaparwa yang mengisahkan tentang Pandawa yang mengalami pembuangan di hutan Kamyaka selama dua belas tahun. Karya Arjuna Wiwaha berbentuk kakawin dengan menggunakan bahasa Jawa Kuno yang mana menceritakan Arjuna sebagai seorang Witaraga, yaitu sosok yang bebas dari keinginan dan nafsu-nafsunya (Sulaksono, 2011. Tesis). Dalam bahasa Jawa Baru Witaraga dikenal sebagai Mintaraga, sebuah cerita dengan tokoh Arjuna 
yang melakukan pertapaan di gunung Indrakila, gua Mintaraga, untuk mencapai kesempurnaan hidup.

Lakon Mintaraga sajian Wayang Wong Sriwedari menjadi salah satu lakon yang menarik untuk dikaji secara tektsur pertunjukan. Bentuk Pertunjukan ini mengandung banyak dialog, mood, spektakel dan bentuk gending yang unik dan berbobot. Hal tersebut dikarenakan pertunjukan lakon Mintaraga digarap secara total selama hampir tiga bulan. Tidak seperti lakon lakon sebelumnya yang hampir tidak ada latihan saat akan pentas. Lakon wayang wong biasanya hanya melalui proses penuangan satu jam sebelum dipentaskan. Nampaknya lakon Mintaraga ini digarap secara baik oleh sutradara Agus Prasetyo karena untuk ditampilkan dalam acara Konggres Senawangi yang di hadiri para seniman dan pejabat pejabat. Oleh sebab itu sangat berbobot jika pertunjukan ini dikaji secara tekstur pertunjukannya.

Penelitian ini merupakan penelitian deskriptif dengan menggunakan metode kualitatif. Dalam hal ini, deskriptif artinya terurai dalam bentuk kata-kata dan tidak menggunakan angka. Sementara itu metode kualitatif didefinisikan sebagai prosedur penilaian yang menghasilkan data deskriptif berupa kata-kata tertulis dari fenomena yang diamati (Moleong, 2007). Bentuk penelitian kualitatif dapat memberikan rincian yang kompleks tentang fenomena yang sulit dijelaskan dengan menggunakan angka. Pemilihan jenis penelitian deskriptif kualitatif ini disesuaikan dengan permasalahan yang akan dibahas serta tujuan penelitian. Untuk membahas permasalahan dan mencapai tujuan penelitian, metode deskriptif kualitatif menggunakan strategi berpikir fenomenologis yang bersifat lentur dan terbuka serta menekankan analisisnya secara induktif dengan meletakkan data penelitian bukan sebagai alat pembuktian, tetapi sebagai modal dasar untuk memahami fakta (Sutopo, 2002, hal. 47). Fakta yang akan dideskripsikan dalam penelitian ini adalah Tekstur Dramatik. Tekstur dramatik adalah unsur-unsur dalam lakon yang menjadi pijakan dalam penyusunan desain pementasan. Jika penjabaran dan analisa struktur dramatik merupakan unsur yang bertujuan untuk menciptakan pemahaman maka tekstur dramatik merupakan bagian dari proyeksi lakon yang sudah dapat dirasakan dan di raba. Adapun yang menjadi bagian dari tekstur lakon adalah: dialog, suasana dan spektakel. Penjabaran tekstur dramatik selengkapnya adalah sebagai berikut:

\section{Dialog}

Dialog adalah percakapan yang terjadi antara tokoh satu dengan tokoh yang lain dalam sebuah lakon. Dialog selain berfungsi memberikan informasi tentang karakter tokoh, juga berperan dalam menciptakan alur cerita, menegaskan tema, latar cerita juga menentukan tempo atau irama permainan.

2. Mood

Yudiaryani dalam mengatakan bahwa irama kalimat, bunyi kata, dan gambaran tokoh yang kaya imajinasi membantu aktor untuk menghadirkan suasana atau Mood. Seorang sutradara harus dapat mendiskusikan gerakan - gerakan ritmis kepada aktor untuk memasuki nuansa kelembutan music. (2002:367). Mood dan rithem sangat penting dalam pementasan teater kerna berpungsi sebagai pembangun suasana dalam pementasan.

3. Spektakel

Spektakel (mise on scene) adalah perwujudan keseluruhan unsur-unsur pementasan yang bersifat audio visual. Spektakel meliputi unsur lakuan, tata artistik, tata cahaya, tata suara atau musik dan segenap pedukung pementasan yang lain.

\section{B. Pembahasan}

\section{Tekstur Dramatik lakon Mintaraga}

\section{a. Pathet Nem}

1. Jejer Kahyangan Suralaya

Tokoh yang ditampilkan: Bathara Guru, Bathara Narada, Bathara Wisnu, Bathara Bayu, Bathara Surapati, Bathara Penyarikan dan dihadap para bidadari Kahyangan. Janturan berikut diucapkan pada adegan jejer untuk melukiskan keadaan Kahyangan Suralaya.

Ampak-ampak sumilak pedhut swuh sukatyuping kang samirana, sumirat surya hamadhangi cakrawala. Kahyangan Suralaya ya ing Jonggringsaloka kawungan suhsuhaning para Dewa nenggih bebisik sang Hyang Guru ya sang Hyang Jagad Giri Nata. Hamarengi kang hanggara kasih mangsa palguna lenggah ing bale raras marcukunda manik, kahayaping hapsara-hapsari den seba Jawata watak nawa kawistingan mrabawa gya hamurwa pangandika rajaning Dewa.

\section{Terjemahan bebas:}

Kabut menghilang tersapu oleh angina, terpancar sinar matahari menerangi cakrawala. Kahyangan Suralaya atau Jonggringsalaka. Terdapat junjungan para dewa yaitu Hyang Guru atau Hyang Jagad Giri Nata. Bersamaan dengan hari selasa kliwon waktu pagi, duduk diatas balai Marcukunda Manik, Dihadapan 


\section{GE $[A R$ Jurnal Seni Budaya}

Hapsara-Hapsari yang bersimpuh bersama Jawata berwatak sembilan, terlihat berwibawa siap menerima perintah Sang raja Dewa.)

Janturan di atas melukiskan keadaan Kahyangan Suralaya dan Karakter tokoh Bathara Guru yang di singgasana sebagai penguasa Kahyangan Suralaya, raja dari segala Dewa, kemudian para dewa yang lain menunggu Bathara Guru memulai pembicaraan. Di dalam persidangan yang agung, Bathara Guru yang dihadap Bathara Narada beserta Bathara Wisnu, Bayu, Surapati dan Panyarikan beserta para dewa-dewi lainnya, Bathara Guru mengungkapkan kecemasannya kepada Bathara Narada yang sedang dialami di kahyangan Suralaya. Perbincangan antara Bathara Guru dan Narada sedikit berbasa-basi sampai pada akhirnya Bathara Narada menjelaskan keadaan Kahyangan kepada Bathara Guru, cuplikan dialog yang menggambarkan kahyangan Jongggringsaloka dilanda masalah.

\section{Naradha}

Heem no, kok nggih ta. Ngaten adhi Guru, niki mung sekedhek kangge gegojekan, sampun ngantos duka ing penggalih mangke masgul. Bathara Guru amung gedheg, estunipun ing dadosaken gara-gara menika wonten titah ing ngarcapada ingkang angka satunggal ingkang wujudipun diyu inggih titah paduka Nirwatakawaca Narendra ing Manimantaka. ingkang minta sihing jawata tumuruning kanugrahaning jawata awujud bathari Supraba, ing angka satunggal. Ingkang angka kalih wonten titah ingkang nembe ngeningaken cipta ngeningaken raos mapan wonten ing Indrakila, adhi guru. Inggih kekalih prekawis menika ingkang ndadosaken goreh rongehing Kahyangan Jonggringsaloka.

Terjemahan bebas:

lya, kok iya ta. Begini adhi Guru, ini hanya sekedar basa-basi, jangan sampai dianggap serius nanti marah. Bathara Guru hanya geleng-geleng. Sebenarnya yang membuat huru-hara di alam dunia disebebkan oleh manusia, yang pertama ialah Niwatakawaca dari Manimantaka yang menginginkan berkah yang berwujud Dewi Supraba, permasalahan ke dua yaitu manusia yang sedang bertapa di Gunung Indrakila, kedua masalah itulah yang membuat huru-hara Kahyangan Jonggringsaloka.
Ginem yang dicetak tebal menggambarkan kepanikan yang dihadapi oleh para dewa karena disebabkan oleh manusia di bumi bernama Prabu Niwatakawaca yang menginginkan Dewi Supraba, dan kedua disebabkan oleh pangaribawa Raden Arjuna yang sedang bertapa di Gunung Indrakila. Kemudian disekat dengan Ada-ada Greget Saut Jugag yang menggambarkan para Dewa yakni Suropati, Bayu, Wisnu, dan Panyarikan melontarkan semua permasalahan yang sama seperti halnya yang sedang terjadi di Kahyangan Suralaya.

Kemudian disekat dengan Ada-ada Greget Saut untuk menambah suasana sereng di Kahyangan Suralaya, selanjutnya dilanjutkan dialog dan adegan Para Dewa seperti Bathara Surapati, Bayu, Wisnu dan Panyarikan menambahkan pembicaraan yang menyangkut perihal kekacauan di Kahyangan Surala. Bathara Narada menyambung pembicaraan dengan Bathara Guru dan menjelaskan kembali manusia yang termasuk golongan Sura dan Asura dalam kitab Jitabsara yang menjelaskan tentang terjadinya Perang Guntarayana yang akan terjadi kepada Bathara Guru. Adegan disekat dengan Ada-ada Greget untuk menggambarkan para Dewa kembali ke Singgasana dan Para Bidadari menuju ketempat Begawan Ciptaning melaksanakan tugas dari dewa untuk menggagalkan tapabrata Begawan Mintaraga.

\section{Adegan Gua Mintaraga/Gunung Indrakila}

Tokoh: Dewi Supraba diikuti oleh bidadari lainnya, Begawan Ciptaning.

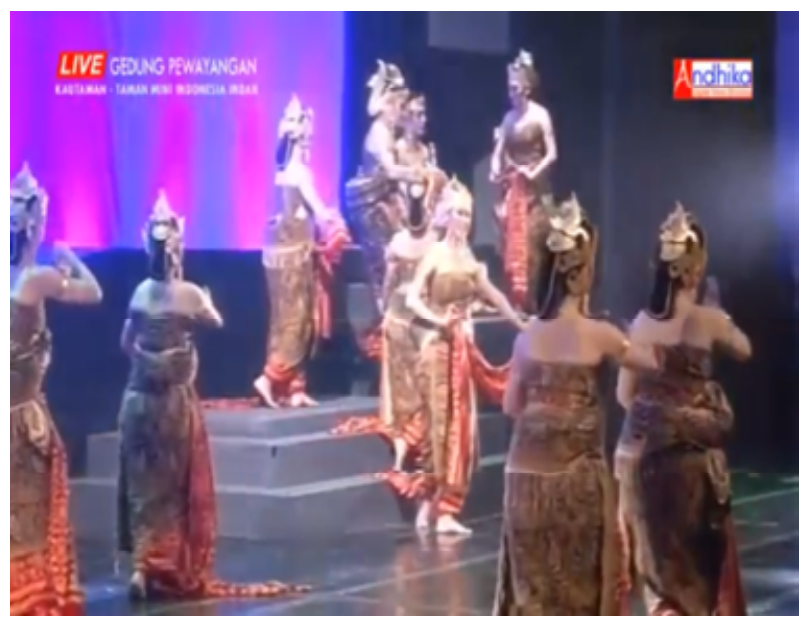

Gambar 1. Adegan Gunung Indrakila, Begawan Ciptaning sedang dikerumuni Bidadari yang ingin menghentikan semedinya. (foto Andhika Multimedia repro wayang wong Sriwedari, 25 April 2017) 
Pada gambar (foto di atas) menggambarkan adegan para Bidadari yang mendapatkan tugas dari Dewa untuk menemui Begawan Ciptaning dan menggoda tapa Begawan Ciptaning, karena efek kekuatan Begawan Ciptaning bertapalah yang membuat Kahyangan Jonggringsaloka menjadi kacau. Para bidadari mendekati Arjuna, seperti halnya Dewi Supraba yang membisik Begawan Ciptaning agar tidak meneruskan semedinya, kemudian para bidadari lainnya seperti Warsiki, Tunjung Biru, dan Wilotama ikut menggoda Ciptaning. Adegan ini diakhiri dengan gagalnya para Bidadari menggoda tapa Begawan Ciptaning, karena disebabkan Begawan Cipotaning mengeluarkan kekuatan untuk menyingkirkan para Bidadari tersebut sehingga terpental oleh pangaribawa dari tubuh sang Ciptaning. Akhirnya para bidadari kembali ke kahyangan untuk melaporkan bahwa tugas untuk menggagalkan tapa Begawan Ciptaning berimbas dengan kegagalan.

\section{Adegan candhakan Gunung Indrakila}

Tokoh yang tampil: Resi Padya dan Begawan Ciptaning.

Setelah para bidadari gagal dalam menggoda Begawan Ciptoning saat bertapa, disekat dengan Adaada Greget Saut untuk menggambarkan kedatangan Resi Padya yang akhirnya menemui Begawan Ciptaning di Gunung Indrakila, dalam ginem (Bantah)sebagai berikut:

\section{Resi Padya}

Heh satriya, kang mara tapa ora sabenah titah bisa lumebu ana Indrakila miwah Kang gawate kepati-pati, hamung satriya kang pinunjul kang bisa lumebu ana ing Mintaraga. Tak sawang akehing bebondhotan kang tan rinasa dhuwuring gunung miwah jeroning jurang tan bisa mendaake kang dadi kekarepanira. Nanging kuciwane maksih duwe rasa tidhatidha lan sanggarunggi katitik anggon sira teteki maksih nyanding bedhama miwah pusaka.

\section{Ciptaning}

Manungsa darbe sipat kang mawarna-warna manut ilining toya. Maksih kedunungan dedosa, melu marang ilining getih darbe rasa jirih, anut marang ilining lathi kadunungan napsu, tri tunggal tan kena pinisah lamun pinerang sawiji wus mesthi kinukut jagoning pati.

\begin{abstract}
Resi Padya
Gegayuhan mono kudu ginayuh lakuning suku miwah peranganing raga, meneping rasa. kuciwane krasa tidha-tidha lan sanggarunggi ora bisa mungkasi nyawijining rasa cipta karsa lan sedya kang bisa nuwuhaken kanugrahan.
\end{abstract}

\section{Terjemahan bebas:}

\section{Resi Padya}

Heh satriya, yang sedang bertapa, tidak sembarangan orang bisa memasuki Indrakila yang angker, hanya satriya unggul yang bisa masuk dalam Mintaraga (Gua Mintaraga), padahal aku melihat banyak alang-alang yang banyak serta tingginya gunung dan jeramnya jurang, tapi semua itu tidak membuat tekatmu takut. Namun kecewanya masih mempunyai rasa was-was serta belum yakin (berprasangka dalam hati) nyata masih ada pusaka disebelahmu.

\section{Ciptaning}

Manusia itu memiliki beraneka macam sifat seperti mengalirnya air, masih mempunyai dosa, mengikuti aliran darah memiliki perasaan takut, mengikuti alurnya mulut akan mendapatkan napsu, ketiga hal tersebut tidak terpisah walaupun menyatu akan hancur dalam kematian.

\section{Resi Padya \\ Keinginan tersebut dapat diraih karena perjalanan rasa dalam jiwa serta mantapnya rasa/keteguhan dalam diri, kecewa merasa mempunyai rasa was-was serta berprasangka tidak bisa menjadikan bersatunya rasa cipta dan karsa, dan tekat yang berubah menjadi anugrah.}

Dalam percakapan di atas Resi Padya yang terkesan dengan kegigihan Ciptaning mampu masuk dalam Gua Mintaraga yang jelas gunung tersebut berbahaya, namun Resi Padya masih mempunyai rasa kecewa karena suatu hal yaitu Begawan Ciptaning masih mempunyai sifat kurang yakin dan rasa waswas dalam dirinya terbukti masih membawa sebuat senjata untuk berjaga-jaga. Namun Begawan Ciptaning menyangkal semua itu, kemudian menjelaskan maksudnya masih membawa sebuah senjata kepada sang Resi Padya. Percapakan (Jawa:Bantah) tersebut diakhiri dengan kemarahan Resi Padya yang tidak 


\section{GELAR Jumal saib butsya}

setuju dengan perkataan Begawan Ciptaning. Hal ini dapat dilihat dalam ginem sebagai berikut:

\section{Resi Padya}

Yen mangkono beda juntrunge... (disekat iringan kemudian sirep dilanjutkan dialog) wis wani ngagem asma Ciptaning. Nanging during ngerti werdine, cipta gegayuhan utama panjangka hening, heninging cipta hindriya, satriya mono lamun wus bisa ninggalake kadonyan ateges ora bisa neterake rasa kasatriyane. Nanging beda sira resi, teteki wae maksih nyandhing bedhama miwah pusaka. Yen mono sira maksih kelu gebyaring kadonyan. Ya mung yomani kang cinandhi.

Terjemahan bebas:

\section{Resi Padya}

Jika seperti itu beda jalannya....sudah berani menggunakan nama Ciptaning tetapi tidak tahu artinya/gunanya, keyakian keinginan, satriya itu walaupun bisa meninggalkan duniawinya tidak bisa melihatkan rasa kesatriannya. Namun berbeda seperti kamu, menyepi masih memerlukan pusaka, jika seperti itu masih memikirkan dan terpikat oleh eloknya dunia, hanya neraka tempatmu.

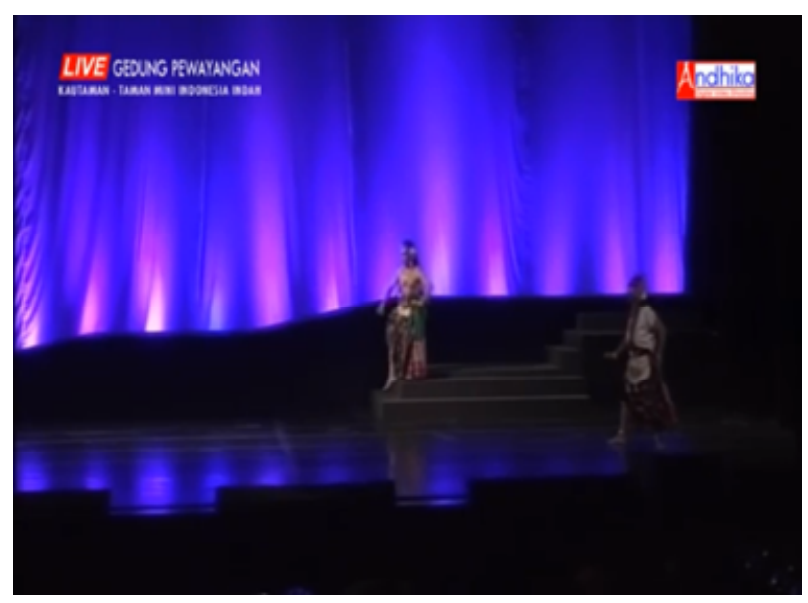

Gambar 2. Adegan Begawan Ciptaning bertemu dengan Resi Padya. (foto Andhika Multimedia repro wayang wong Sriwedari, 25 April 2017)

\section{Adegan Candhakan II Gunung Indrakila}

Tokoh yang tampil: raskasa bermuka celeng (Babi Hutan), Keratarupa dan Begawan Ciptaning.

Setelah perginya Resi Padya dari hadapan Begawan Ciptaning, tidak lama kemudian terdengar suara gemuruh yang disebabkan oleh rasaksa bermuka celeng yang menghampiri tempat Begawan Ciptaning. Bersamaan dengan keluarnya Keratarupa. Rasaksa celeng kemudian mendekati Begawan Ciptaning, adegan ini bisa dilihat dalam gambar sebagai berikut:

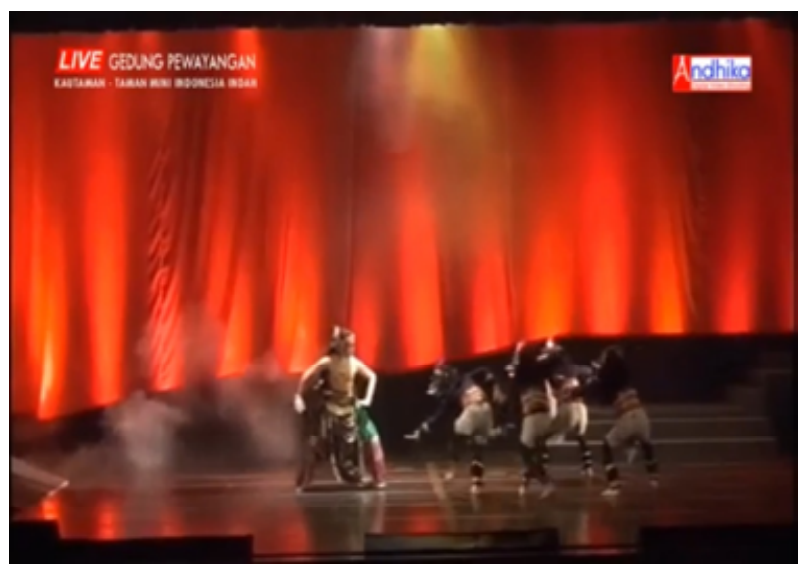

Gambar 3. Adegan Begawan Ciptaning dihampiri oleh segerombolan raksasa bermuka Celeng. (foto Andhika Multimedia repro wayang wong Sriwedari, 25 April 2017)

Begawan Ciptaning kemudian mengeluarkan pangaribawa dalam tubuhnya untuk menyingkirkan para raksasa bermuka celeng, raksasa Celeng yang terkena pangaribawa dari Begawan Ciptaning kemudian kalang-kabut dan menjauh dari Ciptaning. Disekat dengan Ada-ada Greget Saut Nem, selanjutnya muncul Keratarupa dan menghampiri Begawan Ciptaning, kemudian dilanjutkan dengan perang antara Keratarupa dengan Begawan Ciptaning menggunakan keris. Perang antara Keratarupa dengan Begawan Ciptaning tidak ada yang kalah maupun menang. Oleh sebab itu, peperangan diakhiri dengan adegan Begawan Ciptaning dan Keratarupa yang kemudian muncul para Bidadari (sudah ditimpa dengan tembang iringan sirep) untuk menggambarkan bahwa Keratarupa tersebut ialah jelmaan dari Bathara Guru, yang sebenarnya membutuhkan kekuatan serta pertolongan untuk mengalahkan Prabu Niwatakawaca raja Manimantaka, Begawan Ciptaning ditemani oleh Dewi Supraba untuk bersama-sama mengalahkan Niwatakawaca. Adegan ini dapat dilihat dalam gambar sebagai berikut: 


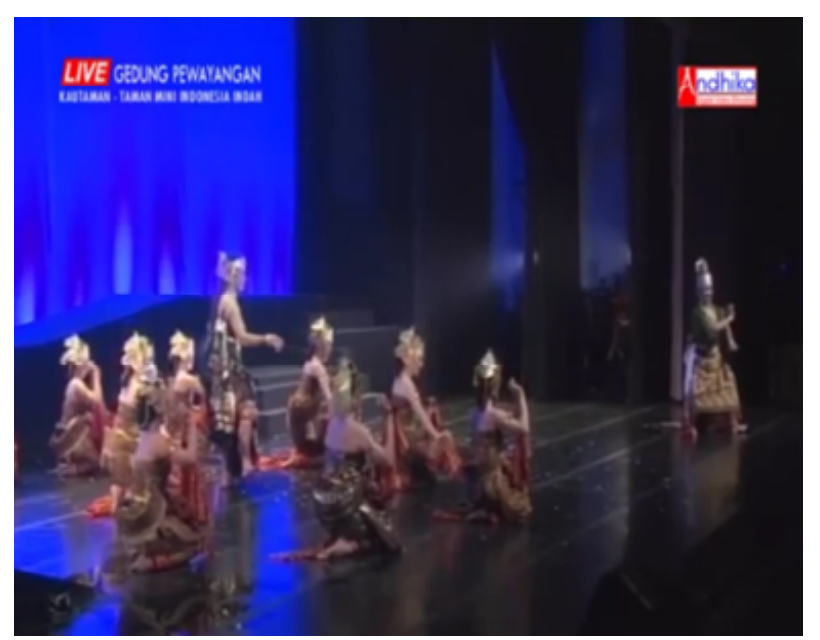

Gambar 4. Adegan Keratarupa dengan Begawan Ciptaning sedang dikerumuni oleh Bidadari, yang sebetulnya untuk mengiringi Keratarpa untuk kembali kewujud asli menjadi Bathara Guru. (foto Andhika Multimedia repro wayang wong Sriwedari, 25 April 2017)

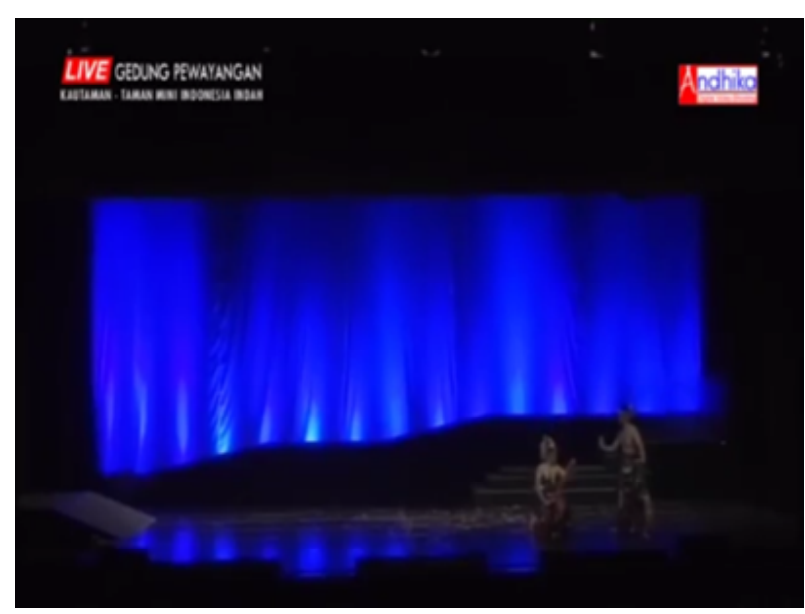

Gambar 5. Adegan Bidadari Supraba dengan Begawan Ciptaning yang bersama-sama pergi untuk mengalahkan Prabu Niwatakawaca.

(foto Andhika Multimedia repro wayang wong Sriwedari, 25 April 2017)

\section{b. Pathet Sanga}

1. Adegan Gara-gara dan Bagong

Tokoh yang tampil: Semar, Gareng, Petruk,

Para Punakawan yaitu Gareng, Petruk, dan Bagong sedang asyik bercanda ria, untuk mengisi kekosongan waktu, keadaan hati yang riang Gareng, Petruk, dan Bagong pun memainkan tokoh rasaksa Cakil dengan bergantian canda dan tawa. Hal ini dapat disimak melalui dialog sebagai berikut.

\section{Petruk \\ Kowe jur ngasak wae perangmu kapan? (kamu hanya ngawur saja perangmu kapan?) \\ Gareng \\ Ngenteni perang ta iki? \\ (menunggu perang ya ini?) \\ Petruk \\ Lawong jenenge mlaku bambangan. \\ (namanya juga jalannya Bambangan) \\ Gareng \\ La piye? Meh perang ngasake wae ing kana. (Iha gimana? Mau perang ngawur terus disana) \\ Disaut petruk}

Hee.. kowe kuwi ndadak ing kene..mbok ngarep lawang kana! Karo gawa bathok.

(hee,,kamu itu disini,,sana depan pintu sana! Sekalian bawa tempurung)

\section{Bagong}

Mandheg Gus..... mandheg Guss...

(berhenti Gus......berhenti Gus...)

\section{Gareng}

Gus sapa?

Gus siapa)

\section{Petruk}

Gus Prast po?

(Gus Pras to?)

\section{Bagong}

Suwek Gus.

(robek gus)

\section{Petruk}

kowe kui apa? Dikei jarik kok disuwekkne Iho?

(Lha kamu itu gimana?dikasih kain kok dirusak lho?)

\section{Gareng}

Heh....kudune Cakil kuwi ngasak I nyedaki Bambangan, ngasak og ing pojokan dewe. (Heh....seharusnya Cakil itu mendekati Bambangan, bukannya malah menyendiri sendiri). 


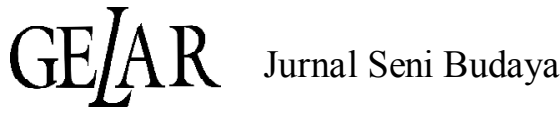

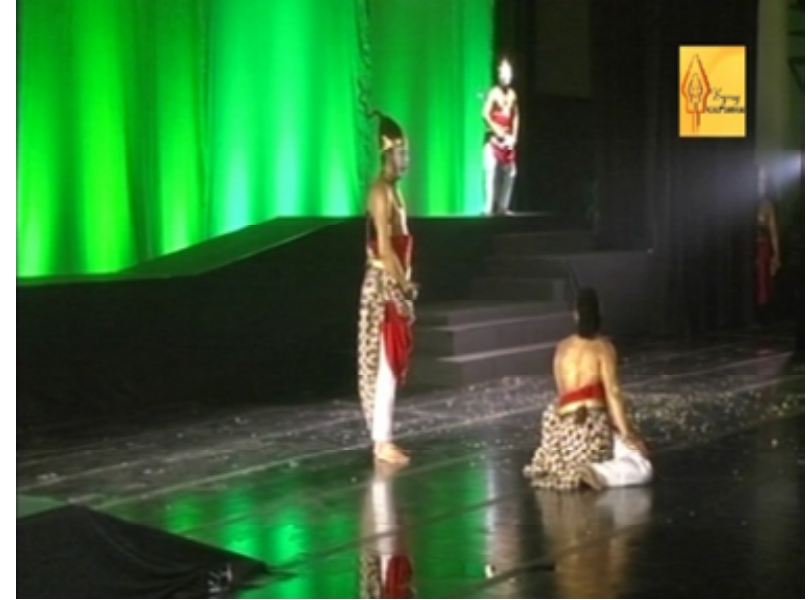

Gambar 6. Adegan Gareng, petruk dan Bagong sedang memerankan tokoh Cakil dan Bambangan.

(foto Andhika Multimedia repro wayang wong Sriwedari, 25 April 2017)

Tidak lama kemudian datanglah Semar menemui Gareng, Petruk, dan Bagong untuk ikut bergabung. Setelah kedatangan semar adegan dalam Gara-gara menampilkan hiburan untuk menghibur para penonton. Selanjutnya pada akhir adegan Semar menasehati anak-anaknya agar hidup sendiri-sendiri karena keadaan di dunia yang sedang kacau balau akibat ditinggal Raden Arjuna.

\section{Adegan Negara Manimantaka}

Tokoh: Prabu Niwatakawaca, Emban Kepetmega dihadap Punggawa Yaksa

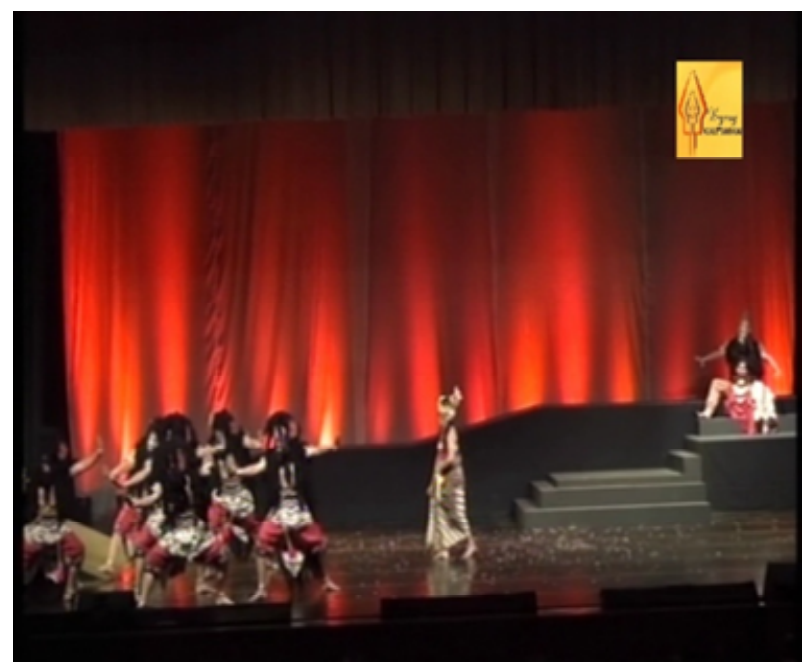

Gambar 7. Adegan jejer Manimantaka, Prabu Niwatakawaca, dihadap oleh Emban Kepetmega dan para Punggawa Yaksa. (foto Andhika Multimedia repro wayang wong Sriwedari, 25 April 2017)
Prabu Niwatakawaca yang pada saat itu terpesona oleh kecantikan Dewi Supraba, dalam bayangnya selalu terbayang-bayang wajah Dewi Supraba. Emban Kepetmega tahu tentang keadaan yang sedang menimpa gustinya tersebut, bersama para punggawa yaksa sengaja menyindir dan mengejek Prabu Niwatakawaca yang sedang jatuh cinta kepada Supraba. Dialog sebagai berikut:

\section{Kepetmega}

Ealahh..alah nek gandrung kadlarung nganti turut lurung, tundhane kaya wong gemblung dleming sajak ora eling ngomyang kaya wong kakean comyang..tobat.tobat.

(Ealahh...alah yang sedang kasmaran sampai seperti orang bingung, ngomong sendiri seperti kebanyakan comyang)

\section{Yaksa}

Apa kui..? aku jaluk comyang ...ora karukaruan,,,malah mikir ..wahahaha..

Apa itu? Aku minta comyang.. nggak karuan...kok malah mikir comyang wahahah)

\section{Kepetmega}

...?whahahaha.. wis-wis aja padha gegojekan seng ora cetha koyo ngono, rene-rene nyaket tak jarwani.

(Stop)...? wahahaha sudah jangan bercanda terusan yang tidak ada gunanya, mendekatlah kesini kepadaku)

\section{Para Yaksa}

Kados pundi...?

(Bagaimana?)

\section{Kepetmega}

Ngene ya bocah yaksa...sejatine aku iki lagi menggalihake sinuwun prabu Nirwatakawaca, kang wektu dina iki lagi gandrung kadlarung klawan Bethari Suprabawati.

(begini ya, sebenarnya aku selalu memperhatikan raja Prabu, yang sedang kasmaran dengan Dewi Suprabawati)

\section{Yaksa}

Whelhaa gandrung?ha mbok wis ben jenenge wong gandrung ki kaya mangkono, mangan ra doyan, turu malah kesusu, pengen penak nanging ra jenak, whehehehaha.

Apa Kasmaran? Yasudah biarkan saja namanya juga lagi sedang jatuh memang 
seperti itu, makan tidak enak, tidur tidak nyenyak, ingin enak tapi tidak kerasan whehehehaha)

\section{Para Yaksa II}

Yen aku ora mangkono, seng baku penting weteng wareg.

(kalau saya tidak seperti itu, yang penting perut kenyang)

\section{Kepetmega}

.....meneng! Ki yen ra tak ngene ora bakal meneng ta? Kabeh kui pancen bener. Nanging sipating amung sawetara, kamangka tentreming praja kuwi gumatung saka panguwasa kang gelem mulat marang kawulane. Kamangka yen ta iki amung mikirake rasa dimen ceblok bisa-bisa kahanane kawula ora padha mukti nanging okeh sing padha mati merga rumangsa radigagas karo sesembahane.

(Diam...diam! Bila tidak mungkin tidak akan berhenti bicara? Itu semua memang benar. Tetapi hanya sementara, karena tentramnya suatu Negara itu tergantung penguasa yang suka memperhatikan masyarakatnya, bila terus memikirkan soal rasa bisa saja keadaan masyarakatnya tidak akan tentram namun banyak yang akan mati disebabkan tidak dihiraukan oleh pemimpinnya)

\section{c. Pathet Manyura}

Setelah perbincangan Emban Kepetmega dengan para Punggawa raksasa, tidak lama kemudian Prabu Nirwatakawaca menggertak dan berteriak, karena mendengarkan celotehan Emban Kepetmega dengan punggawa raksasa. Setelah mengetahui Prabu Niwatakawaca marah, Emban kepetmega dan punggawa yaksa terkejut. Dialog Prabu Niwatakawaca sebagai berikut:

\section{Niwatakawaca}

Hong tete mas patik raja dewaku, pancen kepara nyata yen ta jeneng ingsun narendra kang ora bisa diasorake dewa bakal tak byuki bandha donya supayane ngakoni marang kalungguhaningsun minangka jejering narendra kang lungguhi bale kencana jagad raya.

(memang kenyataan bahwa saya raja yang sulit untuk ditakluhkan bahkan dewa sekalipun, akan aku perlihatkan kekayaanku, supaya mengakui kedudukanku sebagai raja seluruh jagad raya)

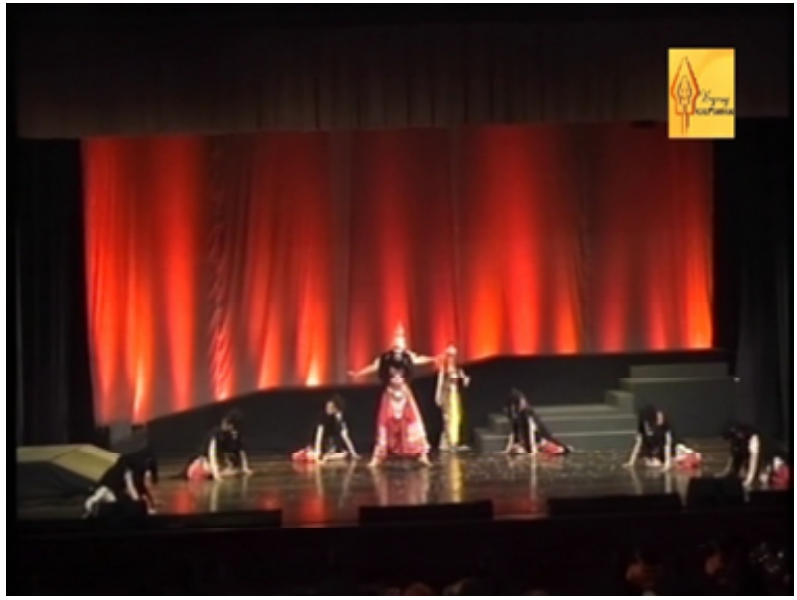

Gambar 8. Adegan yang menggambarkan Prabu Niwatakawaca menggertak kepada Kepetmega dan Punggawa Yaksa. (foto Andhika Multimedia repro wayang wong Sriwedari, 25 April 2017)

\section{Adegan Candhakan Praja Manimantaka}

Tokoh: Begawan Ciptaning dan Prabu Niwatakawaca serta Punggawa Yaksa, Kepetmega.

Adegan diakhiri dengan kedatangan Begawan Ciptaning ke Niwatakawaca tempat singgah Prabu Niwatakawaca. Kedatangan Begawan ciptaning bermaksud untuk membinasakan Prabu Niwatakawaca atas perintah Dewa Suralaya. Dialog sebagai berikut.

\section{Niwatakawaca}

He..he..he..he ana pawongan cahyane sumunar hanelahi kraton ing Himaimantaka, sapa kowe gus ngakua, ngakua?

(He..he..he..he ada manusia sinarnya menyelimuti keraton ing Manimantaka, siapa sebenarnya kamu gus, mengakulah?)

\section{Ciptaning}

Ingsun dutaning jawata kang bakal muna satrumurka, dewa ora babag klawan kaprawiran. Ya mung aku kang bakal mungkasi karya.

(prajurit dewa yang akan melenyapkan angkaramurka, dewa bukanlah lawanmu, hanya aku yang akan menyelesaikan tugas ini)

\section{Nirwatakawaca \\ Whahahahhaha... gedhemu ora sepiroa karosanmu kaliwat liwat, klakon dak kipatne mbledhuk kwandamu. \\ (whahahahaha...tidak seberapa besar kekuatanmu, bersiaplah kubanting tubuhmu).}




\section{GE[AR suman scer Bublysa}

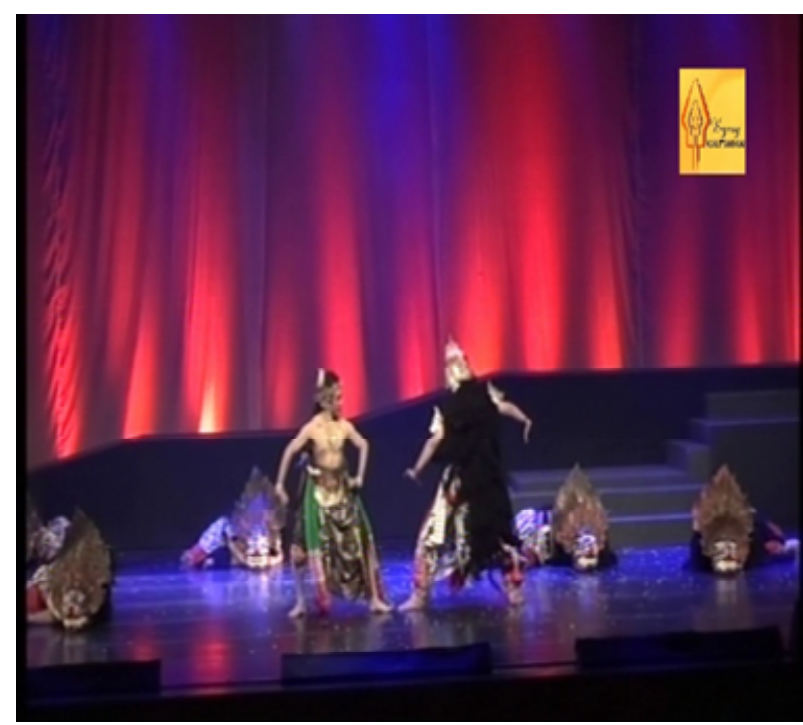

Gambar 9. Adegan perang Ciptaning berhadapan dengan Niwatakawaca di Manimantaka. (foto

Andhika Multimedia repro wayang wong Sriwedari, 25 April 2017)

Perang besar Guntarayana antara Prabu Niwatakawaca dengan Begawan Ciptaning berlangsung, tidak lama kemudian Dewi Supraba datang untuk membantu Begawan Ciptaning, Dewi Supraba mendekati Prabu Niwatakawaca yang keadaan saat itu masih menggebu-gebu cintanya kepada Supraba. Dialog sebagai berikut.

\section{Niwatakawaca}

Supraba lilakno wektu dina iki, jeneng ingsung kesandhung, kacencang ing dhadhung kasrimpet uthet-utheting wanodya kang sulistya ing warni, suaramu arum mangambar mawa nimbus ing dhadha. Adoh tak awe, cedhak tak caketake. Supraba, esmu hameksa aneng pamucuking pangidep. Ayoayo bebarengan ngumba katresnan kang sejati. Whahahaha Supraba, Supraba whahahaha.

(Supraba berikan waktumu hari ini untukku yang sedang kasmaran ibarat terikat tali yang melilit dalam cinta seorang wanita sepertimu, suaramu merdu sampai menembus dada. Jauh ku gapai, dekat ku rekatkan. Supraba, senyummu terlihat dimataku. Ayo-ayo bersama kita memadu kasih sejati, whahaha. Supraba..Supraba..Whahaha)

Dialog di atas membuktikan bahwa Prabu Niwatakawaca sangat menginginkan Dewi Supraba, Dewi Supraba yang datang akhirnya bekerja sama dengan Begawan Ciptaning untuk mengalahkan Niwatakawaca dengan cara membidik Pasupati tepat mengenai rongga mulutnya hingga meninggal dunia.

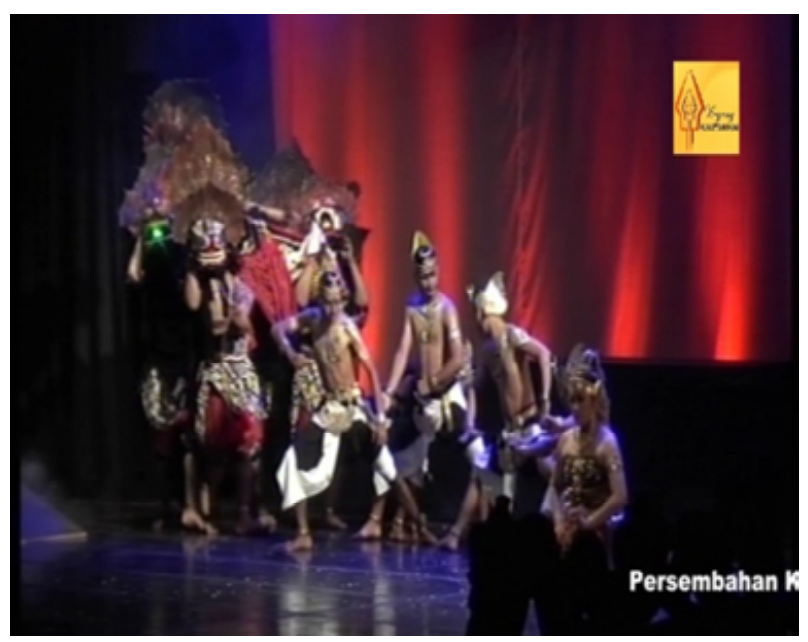

Gambar 10. Adegan Prabu Niwatakawaca yang telah terkena Pasupati milik Cipaning, akhirnya tumbang dan kemenangan didapatkan oleh

Begawan Ciptaning. (foto Andhika Multimedia repro wayang wong Sriwedari, 25 April 2017)

Setelah kematian Prabu Niwatakawaca, para dewa pun menghampiri Begawan Ciptaning, karena jasanya yang telah berhasil menumpas angkara murka di muka bumi. Para dewa akhirnya memberikannya julukan Prabu Kariti.

\section{Kesimpulan}

Lakon Mintaraga merupakan sebuah lakon yang menceritakan perjalanan tokoh Arjuna dalam pertapaan. Berawal dari keteguhan Arjuna dalam bertapa hingga mendapatkan tugas dari Para dewa untuk menumpas keangkaramurkan yaitu Prabu Niwatakawaca. Wayang Wong Sriwedari nampaknya berhasil menggarap lakon tersebut dengan didukung elemen elemen mulai dari musik, setting, lighting hingga properti yang selaras. Hal yang mengenai pementasan yang dapat dirasakan semua indera oleh penonton inilah yang sangat penting untuk di bahas secara terperici. Hal tersebutlah yang dinamakan tekstur sebuah pertunjukan. Dalam pertunjukan wayang wong sudah di bakukan dengan tiga babak. Babak tersebut berisi pathet nem, pathet sanga, dan Pathet manyura. Dalam setiap babak tersebut berisi sub sub adegan. Setiap adegan dalam Wayang wong Sriwedari inilah yang digarap secara detail baik secara visual dan audio visual. Kajian tekstur Lakon Mintaraga 
Sajian wayang Wong Sriwedari melihat setiap adegan dan menganalisis sesuai dengan tangkapan indera yang dilakukan peneliti. Analisis tersebut mengacu pada sebuah teori tektual yang dikemukakan oleh Satoto.

\section{KEPUSTAKAAN}

Ambarwati, R.Struktur Dramatik Lako Jaka Kendhil Ketoprak Bocah Ari Budaya. Semarang: Universitas Negeri Semarang. 2015.

Amir, H. Nilai-Nilai Etis dalam Wayang. Jakarta: Pustaka Sinar Harapan. 1994.

Azhari, D. M. "Eksistensi Wayang Orang (Studi Deskriptif Eksistensi Kelompok Wayang Orang Sriwedari Surakarta di Surakarta)". Antro Unair dot Net Vol. IV Nomor 2, 175-186. 2015.

Endraswara, S. Metode Pembelajaran Drama. Yogyakarta: Caps. 2011.

Haryaningsih Dewi, Mumuh, Gunardi Gugun "Kajian Psikologi Individu Dalam Penggambaran Tokoh Drama Mainan Gelas Karya Tennesee Wiliams". ISBI Bandung : Jurnal Panggung vol 24 no 1. 104-105). 2014

Dyah Gayatri Puspitasari "Narasi Cahaya Kearifan Lokal Dalam Film Sang Pencerah Karya Hanung Bramantyo ". ISBI Bandung: Jurnal Panggung vol 26 n.4, hal 366-367. 2016.

Harymawan. Dramaturgi. Bandung: Remaja Rosdakarya. 1993.

Hersapandi . Wayang Wong Sriwedari: Dari Seni Istana menjadi Seni Komersial. Yogyakarta: Tarawang. 1999.

Moleong, L. J. Metodologi Penelitian Kualitatif. bandung: Remaja Rosdakarya. 2007.

Nurgiyanto, B. Teori Pengkajian Fiksi. Yogyakarta: Universitas Gadjah Mada Press. 1998

Sahid Nur., Kajian Sosiologis Terhadap Tema Lakon 'Domba-domba Revolusi' Karya Bambang
Soelarto". ISBI Bandung: Jurnal Panggung vo 24 no 1. hal 4.2014 “

Satoto, S. Wayang Kulit Purwa Makna dan Struktur Dramatiknya. Surakarta: Depdikbud. 1985.

Analisis Drama dan Teater. Yogyakarta: Penerbit Ombak.. 2012.

Soedarsono, R. Wayang Wong: The State Ritual Dance Drama in the Court of Yogyakarta. Yogyakarta: Gadjah Mada University Press. 1984 .

Sudikan, S. Y. Metode Penelitian Sastra Lisan. Surabaya: Citra Wacana. 2001.

Sulaksono, D. Tesis.:" Struktiur dan Nilai Pendidikan Cerita Mintaraga Gancaran Karya Prijohoetomo". Surakarta: Universitas Sebelas Maret. 2011.

Sutopo, H. Pengantar Penelitian Kualitatif. Surakarta: UNS Press. 2002.

Sunardi, Nogroho Sugeng, Kuwato "Pertunjukan Wayang Babad Nusantara: Wahana Pengajaran Nilai Kebangsaan Bagi Generasi Muda". ISBI Bandung : Jurnal Panggung vol 26 no 2. 196-197). 2016.

Supartono Tony. "Penciptaan teater Tubuh" . ISBI Bandung: Jurnal Panggung vol 26 no 26. 209210. 2016.

Suyanto " Menggali Filsafat Wayang beber Untuk Mendukung Perkembangan Industri Kreatif Batik Pacitan", ISBI Bandung: Jurnal Panggung vol 21 no. 1, 88-89. 2017 .

Waluyo . Pengkajian dan Apresiasi Prosa Fiksi. Sukarkarta: UNS Press. 2011.

Waluyo, H. J. Drama: Teori dan Pengajarannya. Yogyakarta: Hanindita. 2002.

Winoto . Sejarah dan Kondisi Wayang Wong Sriwedari di Surakarta. Surakarta: ISI Press. 2006. 